\title{
COMPULSORY LICENSING IN THE INDUSTRIAL AND COMMERCIAL ARENA: A COMPROMISE
}

Compelling a person to allow others to use his property evokes discussion and some protest. Some claim that such compulsion is contrary to traditional American principles, ${ }^{1}$ and others question the constitutionality ${ }^{2}$ or the fairness ${ }^{3}$ of the practice. Yet there are situations where the exclusivity of ownership of intangible forms of personal property sucl as patents, trademarks and copyrights conflicts with other equally compelling interests and inust: be modified by licensing that property to the use of another. This can occur, for instance, when there has been a violation of the antitrust laws, when a compelling public health or safety factor is present, or under some circumstances when an agency or contractor of the government requires the use of a particular patent.

This Comment surveys those situations in which the compulsory license may be used to accommodate the desire to protect the interest of the public with the desire to reach a fair result in litigation or to define in a fair manner the legal relations between parties. ${ }^{4}$ When there is a violation of the antitrust laws stemming from the misuse of valid patent rights, the limited monopoly of the patent and the antimonopoly dictates of the antitrust laws must be reconciled. If the public health or safety might be adversely affected by the use or nonuse of a patent, a method of protecting the public and of recognizing the property right of the patent owner must be found. When the government requires the use of a patent on a public project, the interests of the patent owner and of the public must be considered together. If the grant of a patent on an invention might impair the national security, the patent-granting process must be modified in the national interest. And when litigation in a private trade secret case threatens to delay the production of a crucial military product, the vital governmental interest may affect the outcome of the dispute.

\footnotetext{
1 See, e.g., Riesenfeld, Compulsory Licenses and United States Industrial and Artistic Property Law, 4T CaLIF. L. REv. 51 (1959).

2 See, e.g., Note, Compulsory Licensing: A Controversial Topic in the Latest Revision of Our Copyright Law, 33 U. Civc. L. Rev. 83, 94-98 (1964).

3 See, e.g., Staff of House Contas. on the Judictary, 88tr Cong., 1st Sess., Coryright Law Revision, Part 2: Discission \& Comments on Repgrt of the Register of COPYRIGHTS ON THE General Revision of THE U.S. Coprriget LaW 59-72 (Comm. print 1963) (testimony of Julian T. Abeles).

4 This Comment will not deal with the compulsory licensing provision in the Copyright Act. The current provision and the proposed revised version have been thoroughly discussed in recent law review articles. See Comment, Comspromise to a Correct Resull: Retention and Modification of the Compulsory License in Proposed Copyright Law Revision, 53 CaIIF. L. REv. 1520 (1965); Note, Compulsory Licensing: A Controversial Topic in the Lalest Revision of Our Copyright Law, 33 U. Conc. L. Rev. 83 (1964).
} 
It will be evident from the ensuing sections that the compulsory license is used only in situations in which the public interest mtrudes upon the individual rights and duties of private parties. And it will be seen that such intrusions, though sought to be minimized in our legal system, do occur. When they do, the compulsory license is often the most equitable resolution of the conflict.

\section{I}

\section{GENERAI PATENT IICENSING}

Commentators have noted that the American concept of the inventor's right to use and profit from his invention has impeded the enactment of broad compulsory patent hicensing schemes $;^{5}$ however, most writers acknowledge that licensing is proper under certain circumstances. ${ }^{6}$ The patent grant vests a property right in the patentee. ${ }^{7}$ Although the patent is granted for very special reasons-to foster invention and to reward the inventor-it is still property in the same sense that a certificate of stock or a chattel mortgage is property and is subject, as they are, to limitation through the proper use of governmental power. ${ }^{8}$

\section{A. Prerogative of the Federal Government}

Prior to 1910 , under the doctrine of sovereign immunity, the federal government could not be sued for patent infringement unless it consented. ${ }^{9}$ An act of Congress $m$ that year consented to suits on patent infringement claims but provided that suit could be brought only in the Court of Claims. ${ }^{10}$ The patent owner could obtain reasonable compensation but could not enjoin the government from using his patent. ${ }^{11}$ In 1918 the act

6 Riesenfeld, supra note 1, at 52; Note, Injunctive Relief in Patent Infringement Suits, 112 U. PA. L. Rev. 1025, 1048 (1964).

6 See, e.g., Stocknig \& Watkms, Monopoly AND Free Enterprise 454-68 (1951); Nordeaus \& JURow, Patent-Antitrust Law § 129 (1961).

7 United States v. Dubilier Condenser Corp., 289 U.S. 178, 187 (1933); Seymour v. Osborne, 78 U.S. 516, 533 (1870); Brown v. Duchesne, 60 U.S. 183, 195 (1856).

8 See note 14 infra. The licensing situations presented in this section should be distinguished from the implied license found in general patent law. When the latter concept is applied, the patentee may not enforce the exclusivity of his patent right, but for reasons similar to estoppel rather than because the public interest has intervened. See 4 WAIKER, Patents \$\& 392-96 (Deller ed. 1965). An implied license may be found when the owner of a patent joins a partnership which has a use for the patent, Mueller v. Mueller, 95 Fed. 155 (3d Cir. 1899); where the owner of a patent sells a machine that incorporates the patent, Societé Fabriques v. Franco-American Trading Co., 82 Fed. 439 (C.C.S.D.N.Y. 1897); and when an employee invents a process or machine in the normal course of his employment, United States v. Dubilier Condenser Corp., 289 U.S. 178, 188 (1933).

${ }^{8}$ See Crozier v. Fried. Krupp, 224 U.S. 290, 304 (1912).

1036 Stat. 851 (1910) (now 28 U.S.C. $\$ 1498$ (1964)).

11 Ibid. 
was amended to provide that patent infringement actions involving government contractors could be brought only in the Court of Claims. ${ }^{12}$ The Supreme Court recognized that one purpose of the original act was to protect inventors from the uncompensated appropriation of their inventions. ${ }^{13}$ And, when dealing with a case involving guns and gun carriages, the Supreme Court also recognized as an undemable effect of the act that,

in view of the pubhic nature of the subjects with which the patents in question are concerned and the undoubted authority of the United States as to such subjects to exert the power of eminent domain, the statute, looking at the substance of things, provides for the appropriation of a license to use the inventions, the appropriation thus made being sanctioned by the means of compensation for which the statute provides. $^{14}$

Other congressional solutions might have been advanced, such as patent expropriation, or compelling the patentee to sell the patent, or allowing the patent owner to decide freely whether or not to license his patent to the government. But any of these solutions would have resulted in a lopsided distribution of rights favoring either the government or the private party. Licensing protects the patentee, yet makes patents available to the government if they are needed on a pubhic project.

1240 Stat. 705 (1918), amending 36 Stat. 851 (1910) (now 28 U.S.C. \& 1498 (1964)), beld constitutional in Richmond Screw Anchor Co. v. United States, 275 U.S. 331 (1928). The 1918 amendment superseded a decision of the Supreme Court which beld that government contractors were not immune, under the 1910 act, fron patent infringement suits. William Cramp \& Sons Ship \& Engine Bldg. Co. v. Int'l Curtis Marine Turbine Co., 246 U.S. 28 (1918).

13 Richmond Screw Anchor Co. v. United States, 275 U.S. 331, 341 (1928).

14 Crozier v. Fried. Krupp, 224 U.S. 290, 305 (1912). As Crozier suggests, the compulsory license can profitably be considered in the light of the two traditional propertytaking powers: the power of eminent domain and the police power. The power of emment domain is based on the sovereignty of the state over all property within its jurisdiction. The police power is based on the authority of the state to regulate the activities that transpire within its borders so that the health, safety and welfare of the citizenry, as a whole, is protected.

The fifth amendment to the United States Constitution provides that "private property [shall not] be taken for public use, without just compensation." However, legally acquired rights in existing economic values may be impaired, and yet no compensation paid, in a multitude of ways through regulation and legislation advanced under the "police power." For a thorough discussion of the police power see Sax, Takings and the Police Power, 74 YALE L.J. 36 (1964). The author traces the historical development of the two traditional property-taking powers and proffers a rule which defines their scope in terms of their application: "The precise rule to be applied is this: when an individual or limited group in society sustains a detriment to legally acquired existing economic values as a consequence of government activity which enhances the economic value of some governmental enterprise, then the act is a taking, and compensation is constitutionally required; but when the challenged act is an improvement of the public condition through resolution of conflict within the private sector of the society, compensation is not constitutionally required." Id. at 67 . 


\section{B. The Atomic Energy Commission}

Under the 1954 Atomic Energy Act a private party may not own a patent that covers a discovery or invention which "is useful solely in the utilization of special nuclear material or atomic energy in an atomic weapon." ${ }^{115}$ The act requires the inventor to file either a patent application or a report with the AEC. ${ }^{16}$ The Commission, on the application of the inventor, may then grant an award. ${ }^{17}$ Since no patent may be owned, any award granted by the government is not for the confiscation of a property right but is more in the nature of a reward in recognition of a contribution to the welfare of the American people. The act revoked those patents and associated rights which had previously been granted, and which are now covered by the atomic weapons section, and ordered that just compensation be made for the rights taken. ${ }^{18}$ In the critical area of military utilization of atomic energy, Congress has thus gone beyond compulsory licensing; it has declared that no patents for discoveries useful solely in an atomic weapon will be granted to private parties.

Discoveries or inventions which have nonmilitary use in the field of atomic energy may be patented; but the Commission, after a hearing and after making certain findings, ${ }^{19}$ may "declare any patent to be affected with the public interest" ${ }^{20}$ and thereby give the government a license to use the patent and the right to grant a non-exclusive license to third parties. ${ }^{21}$ Furthermore, on the application of persons licensed by the AEC to conduct atomic energy activities, the Commission is required to hold a hearmg and, upon proper findings, ${ }^{22}$ to grant a license to those persons

1568 Stat. 943 (1954), 42 U.S.C. \$ 2181 (a) (1964).

1668 Stat. 943 (1954), as amended, 42 U.S.C. $\$ 2181$ (c) (1964).

1768 Stat. 947 (1954), 42 U.S.C. $\& 2187$ (b) (3) (1964). The grant of an award is subject to judicial review. 68 Stat. 955 (1954), 42 U.S.C. $\& 2239$ (1964).

1868 Stat. 943 (1954), 42 U.S.C. $\$ \S 2181$ (a)-(b) (1964). On the application of the former patent owner the Commission is to determine the amount of the just compensation, 68 Stat. 947 (1954), 42 U.S.C. $\$ \S 2187$ (b) (2), (c)(1), (c)(2) (1964), subject to judicial review, under 68 Stat. 955 (1954), 42 U.S.C. \& 2239 (1964).

19 The Commission must find that "(1) the invention or discovery covered by the patent is of primary importance in the production or utilization of special nuclear material or atomic energy; and (2) the hicensing of such invention or discovery under this section is of primary importance to effectuate the policies and purposes of this chapter." 68 Stat. 945 (1954), 42 U.S.C \& 2183(a) (1964).

20 Ibid.

2168 Stat. 945 (1954), 42 U.S.C. $\$ 2183$ (b) (1964).

2268 Stat. 945 (1954), 42 U.S.C. $\$ \S 2183$ (c)-(e) (1964). In order to compel licensing under this section the Commission must find: "(1) the invention or discovery covered by the patent is of primary importance in the production or utilization of special nuclear material or atomic energy; (2) the licensing of such invention or discovery is of primary importance to the conduct of the activities of the applicant; (3) the activities to which the patent hicense are proposed to be applied by such applicant are of primary importance to the furtherance of policies and purposes of this chapter; and (4) such applicant cannot 
for the use of any nonmilitary atomic energy patent. The owner is then entitled to a reasonable royalty $\mathrm{fe}^{23}$ to be determined by the Commission. ${ }^{24}$ This hicensing scheme seems necessary to effectuate the express congressional pohicy that the AEC shall direct the development, control and use of atomic energy to make the maximum contribution to the general welfare and world peace while maintaining the strength and security of the United States. ${ }^{25}$

\section{Judicial Patent Licensing in the Interest of Public Health or Safety}

In City of Milwaukee v. Activated Sludge, Inc. the city was held to have infringed a sewage processing patent but the Seventh Circuit refused to grant an injunction. ${ }^{28}$ The court stated, "Ordinarily courts will protect patent rights by injunctive process. ... If, however, the injunction ordered by the trial court is made permanent in this case, it would close the sewage plant, leaving the entire community without any means for the disposal of raw sewage other than running it into Lake Michigan, thereby polluting its waters and endangering the health and hives of that and other adjoining communities." ${ }^{\prime 27}$ The court declared that the patent owner could be adequately compensated by a. money judgment. ${ }^{28}$ This was an effectual means of protecting the public interest ${ }^{29}$ while still recognizing the property right of the patent owner. ${ }^{30}$ The willingness of courts to protect

otherwise obtain a patent license from the owner of the patent on terms whicl the Commission deems to be reasonable for the intended use of the patent to be made by such applicant . . ." 68 Stat. 946 (1954), 42 U.S.C. $\S 2183$ (e) (1964). Although § 2183 was enacted as a temporary measure, Congress has twice extended its effective period and it is now valid until Sept. 1, 1969. 78 Stat. 376 (1964). For a description of licensing practices under the 1954 Atomic Energy Act see Dunlavey, Federal Licensing and Atomic Energy, 46 CaIIF. L. Ruv. 69 (1958).

2368 Stat. 946 (1954), 42 U.S.C. $\S 2183$ (g) (1964).

2468 Stat. 947,42 U.S.C. $\$ \S 2187$ (b)(1), (c)(1) (1964). The determination of the amount of the reasonable royalty is subject to judicial review. 68 Stat. $955(1954), 42$ U.S.C. \& 2239 (1964).

25 This express congressional policy is enumerated in the first section of the 1954 Atomic Energy Act. 68 Stat. 921 (1954), 42 U.S.C. § 2011 (1964).

2869 F.2d 577 (7th Cir. 1934).

27 Id. at 593 .

28 Ibid.

29 See also Nerney v. New York, N.H. \& H.R.R., 83 F.2d 409 (2d Cir. 1936) (denial of supplemental injunction to avoid causing interference with the public convenience). $C f$. Thomson-Houston Electric Co. v. Union Ry., 78 Fed. 365 (C.C.S.D.N.Y. 1896), and Westinghouse Air-Brake Co. v. Great Northern Ry., 86 Fed. 132 (C.C.S.D.N.Y. 1898) (injunctions against infringement of industrial patents framed in deference to the public convenience); Campbell Printing-Press \& Mfg. Co. v. Manhattan Ry., 49 Fed. 930 (C.C.S.D.N.Y. 1892) (gradual phase-out of infringing railroad car couplers would minimize the public inconvenience).

$30 \mathrm{Cf}$. the recent California inverse condemnation case, Loma Portal Civic Club v. 
the public health was emphasized in Vitamin Technologists, Inc. v. Wisconsin Alumni Research Foundation. ${ }^{31}$ A group of patents which supposedly covered the irradiation of food products (oleomargarine in this case) were declared invalid on grounds of anticipation, failure to disclose the limits of the claimed monopoly, and laches. ${ }^{32}$ The court indicated that even if the patents had been valid, the foundation would not have been able to enjom the use of the process because the health of the poorer classes was dependent on their ability to obtain vitamins in oleomargarine. ${ }^{33}$

In Bliss v. Brookly $n^{34}$ the owner of a patent on a coupling was unable to obtain an injunction barring the city from its use. The court stated that the safety of the citizenry was at issue as well as the property right of the patent owner "because ... the couplings in question are necessary for the daily use of the city in the prevention of fires. ${ }^{35}$ No injunction was issued because the patent owner would receive adequate compensation if he were paid damages. ${ }^{36}$ The court reached this result despite a state statute which had been passed specifically to eliminate the hability of the officers of the City of Brooklyn to owners of patents. This result may indicate a reluctance to deprive the patent owner of his property without compensation. Such a deprivation might have been permitted under the

American Airlines, 61 Cal. 2d 582, 394 P.2d 548, 39 Cal. Rptr. 708 (1964), where the California Supreme Court upheld the denial of an injunction to landowners who sought to enjoin the flight of jet aircraft to and from Lindbergh Field in San Diego. The court said, "It is well established that public policy denies an injunction and permits only the recovery of damages where private property has been put to public use by a public service corporation and the public interest has intervened. . . This principle is based upon the policy of protecting the public interest in the continuation of the use to which the property has been put, not upon any dilatoriness by a property owner in asserting his rights, nor upon a justification that the property rights were subject in any event to condemnation." Id. at 588-89, 394 P.2d at 552, 39 Cal. Rptr. at 712. The court suggested that the airport had taken an easement and should pay for it. An easenent of this sort may be adequately described as a compulsory license to use real property.

31146 F.2d 941 (9th Cir. 1944).

32 Id. at $949-53$.

33 Id. at 956. The court based its decision in part on its belief that the trend in antitrust cases indicated that the Supreme Court would deny an injunction on the facts of the instant case. The court also found encouragement in a statement of the Supreme Court in Continental Paper Bag Co. v. Eastern Paper Bag Co., 210 U.S. 405 (1908), a case that stands for the proposition that a patentee may refrain from using a patent. "Whether, however, a case cannot arise where, regarding the situation of the parties in view of the public interest, a court of equity might be justified in withholding relief by injunction, we do not decide." Id. at 430.

343 Fed. Cas. 706 (No. 1544) (C.C.E.D.N.Y. 1871).

35 Id. at 707.

${ }^{36}$ See the discussion at note 30 supra and at note 85 infra, on the grant of damages in heu of an injunction when the public interest is affected. See also Southwestern Brush Elec. Light \& Power Co. v. Louisiana Elec. Light Co., 45 Fed. 893 (C.C.E.D. La. 1891) (preliminary injunction denied because street lamps were necessary for the public safety). 
city's police power. If the police power rationale was not applicable, the payment of compensation may have been constitutionally required. ${ }^{37}$ The grant of damages-that is, the decree of a compulsory license for a reasonable royalty - was an equitable solution and obviated the constitutional issue.

\section{Patent Policies of Government Agencies with respect to Research and Development Contracts}

A large percentage of the money spent on researcli and development in the United States is provided by agencies of the federal government. Patentable inventions and discoveries as well as valuable trade processes are bound to be discovered by this government-financed researcl. Two agencies are responsible for the bulk of government expenditures: The National Aeronautics and Space Administration and the Department of Defense. ${ }^{38}$ At present their policies with respect to such discoveries, inventions and processes differ, and illustrate alternative approaches. The Department of Defense, by administrative regulation, groups possible contract situations into three categories and accords the contractors various rights, including, in one category, the right to retain title to any patents obtained in the course of carrying out a contract. ${ }^{30}$ The Department always has the right to acquire royalty-free licenses, ${ }^{40}$ and in certain situations to sublicense other parties. ${ }^{41}$ The policy of NASA, which is based on statutory authorization, ${ }^{42}$ is to acquire the property riglit in

37 See note 14 supra.

38 The Budget of the U.S. Governarent for the Fiscai, Year Endano JUNe 30, 1966 68,86 (1965).

3932 C.F.R. \& 9.107-3 (1965). The three categories and the attendant rights may be summarized as follows: (1) Where the purpose of the contract is to develop processes for the general welfare or where the subject matter of the contract is in a field in which the government is the primary developer, the government normally acquires the property rights to any inventions; (2) where the contract is in an area in which the contractor has previous technical competence, the contractor retains the property rights in any invention; and (3) where it is questionable whether the contractor is primarily utilizing his techmical competence or whether he is branching out into a new field at the expense of the government, the final determination of the ownership of property rights is made hy the contracting officer after the invention is identified. The only opportunity that a contractor might have to object to a categorization by a contract officer would be an appeal to the Armed Services Board of Contract Appeals. On appeal the Board has the authority to review the decisions of contracting officers. But a contractor may appeal only "(a) pursuant to the provisions of contracts requiring the determination of such appeals by the Secretary of Defense or by a Secretary of a Military Department ... or (b) ... pursuant to the provisions of any directive whereby the Secretary of Defense or the Secretary of a Military Department has granted a right of appeal not contained in the contract." 32 C.F.R. \& 30.1 (1965).

4032 C.F.R. $\S \S 9.107-3(\mathrm{~b}),(\mathrm{c}),(\mathrm{b})(1965)$.

4132 C.F.R. \$\$ 9.107-3(f), (g) (1965).

4272 Stat. 435 (1958), 42 U.S.C. $\S 2457$ (1964). 
inventions as a benefit of the contract unless the Administrator of NASA determines that it is in the public interest to waive NASA's rights to the invention. ${ }^{48}$ In the latter case NASA would still retain a royalty-free license to use the invention. ${ }^{44}$

The discrepancy between these approaches reflects the struggle to determine what the proper approach should be. Numerous bills dealing with the ownership of inventions discovered by government contractors have been introduced; ${ }^{45}$ a common denominator seenis to be that government agencies will retain the right to conpel royalty-free licensing. As a Deputy Assistant Secretary of Defense whimsically stated before the McClellan Patents Subcommittee, "We do not wish to pay for having the wheel reinvented each tinie we contract." ${ }^{\prime 4}$

\section{II}

\section{LICENSING FOR VIOLATION OF THE ANTITRUST LAWS}

The grant of a patent creates a legitimate but limited nionopoly; at the same time, the antitrust laws declare certain monopolistic practices to be contrary to the public interest. Use of the limited patent monopoly to create or perpetuate a large-scale monopoly contravenes what the

43 Hearings Before the House Committee on Science and Astronautics on Property Rights in Inventions Made Under Federal Space Research Contracts, 86Tr Covg., 1ST SEss. 2 (1959). Except as previously indicated, the patent policy of the AEC is substantially similar and is also based on a statutory directive. 75 Stat. 477, 42 U.S.C. \& 2182 (1964).

An analogy exists between the accepted practice of requiring employees to assign any patent rights they may acquire to their employers in advance, and that of giving the employer "shop rights" in the patent even if there is no formal assignment. The rational seems to be that an employee sells the application of his professional skills for a fixed remuneration and that the buyer, the employer, should receive any benefit of the application. See Morris, Patent Rights in an Employee's Invention: The American Shop Right Rule and the English View, 39 TEXAs I. REv. 41 (1960).

44 Hearings on Property Rights, supra note 43, at 2. For a description of the policies of government agencies other than NASA, the AEC or the Department of Defense see Stewart, Researce and Developament Contracting 172-74 (1963).

45 E.g., S. 1290, 88th Cong., 1st Sess. (1963); S. 1623, 88th Cong., 1st Sess. (1963); S. 2754, 87th Cong., 2d Sess. (1962); S. 3156, 86th Cong., 2d Sess. (1960). Contractors complain that they lose know-how and trade secrets by the process of "reverse engineering" whereby the government requires the disclosure of technical information so that it may prepare future specifications. When the specifications are made public, the technical inforination is publislied to the world. Private ownership of patents would give the contractors some recompense for their losses. Cf. Whale, Government Rights to Technical Information Received Under Contract, 25 Geo. WaSH. L. REv. 289 (1957); Beach, A Question of Property Rights: The Government and Indistrial Know-How, 41 A.B.A.J. 1024 (1955); Harris, Trade Secrets as They Affect the Government, 18 Bus. LAw. 613 (1963).

For the arguments for and against private ownership of inventions discovered by government contractors see Adams, Business Exemptions from the Antitrust Laws: Their Extent and Rationale, in Perspectrves on ANTIrRUST Potrcy 273, 288 (Phillips ed. 1965). 46 Statement of Graeme C. Bannerman quoted in STEWART, op. cit. supra note 44, at 166 
courts define as the public interest. The claim that a patent has been used in such a manner may arise as a defense in a patent infringment suit or in an antitrust action undertaken by the Justice Department. The defendant may plead or the Justice Department may allege that the patent owner has violated the antitrust laws by monopolizing an industry, by tying-m the sale of an unpatented product with the licensing of a patent or with the sale of a patented product, or by illegally fixing prices. ${ }^{47}$

Several courses of action are open in these cases: sanction the monopoly, protect the patent, and grant relief for any infringment; enjoin the monopolistic practice; decree royalty free licensing; declare the patents invalid; compel the patent owner to divest himself of the patents; or decree compulsory licensing for a reasonable royalty.

\section{A. Patents Used to Monopolize an Industry}

In a series of cases beginning in 1945 the Supreme Court outlawed the use of patents to monopolize trade or stifle competition. ${ }^{48}$ In each case the Court had to enjoin the offending practices and had to formulate a decree to end the illegal monopolization of an industry. These cases were antedated and have been followed by a large number of antitrust suits in the lower federal courts; compulsory licensing provisions have been an integral part of the many remedial decrees. ${ }^{40}$

In United States v. National Lead Co., ${ }^{50}$ the Supreme Court upheld a decree which provided that: "Each of the defendants is ordered to grant

47 One writer, discussing cases in which the conflict between the antitrust laws and the patent monopoly was present, has stated, "at the heart of these suits lies the problem of determining the extent to which the social policy in favor of the freest possible competitive economy shall be modified or limited in favor of the furtherance of other social policies which may result in the creation of monopolies of varying degrees. ... [c]ompetition must be strengthened and revived, for the 'alternative to competition is some form of concentrated governinent authority." Zlinkoff, Monopoly versus Compelition: Significant Trends in Patent, Anti-Trust, Trade-Mark, and Unfair Competition Suits, 53 Yare L.J. 514, 551-52 (1944).

48 Hartford-Empire Co. v. Umited States, 323 U.S. 386, clarified and added to in 324 U.S. 570 (1945); United States v. National Lread Co., 332 U.S. 319 (1947); United States v. United States Gypsunn Co., 340 U.S. 76 (1950) (explained in Urited States Gypsum Co. v. National Gypsum Co., 352 U.S. 457 (1957)); Besser Mfg. Co. v. United States, 343 U.S. 444 (1952); United States v. Umited Shoe Mach. Corp., 110 F. Supp. 295 (D. Mass. 1953), af'd, 347 U.S. 521 (1954). For a discussion in depth of the Hartford-Empire case see Comment, Compulsory Patent Licensing by Antitrust Decree, 56 YAxE' L.J. 77 (1946). For a discussion of these cases from the monopoly standpoint see Srockive \& Watkins, Monopoly and Free Entirrpruse 472-84 (1951); NordhuUs \& JURow, PatentANTITRUST LAW §§ 130-31 (1961).

49 For an exhaustive compilation of those cases which resulted in compulsory licensing decrees during the period 1941-1959 see StafF Report of Senate Comantree on tHe JudIciary, 86tri Cong., 2d Sess., Compulsory patent Licensing Under Antitrust JudgMENTS 55-78 (Comm. Print 1960).

50332 U.S. 319 (1947). 
to any applicant therefor, including any defendant or co-conspirator, a nonexclusive license under any or all of the patents as herein defined at a uniform, reasonable royalty." ${ }^{21}$ Compulsory licensing was upheld because the defendants had used their patents to keep other compamies from producing titanium pigments. The Court expressly left open the question whether a permanent injunction against the enforcement of the patents or royalty-free licensing would have been permissible sanctions if the defendant's conduct had warranted such stringent action. ${ }^{52}$

In a subsequent case the Supreme Court outlined the reasoning that should be followed in such a case:

A trial court upon a finding of a conspiracy in restraint of trade and a monopoly has the duty to compel action by the conspirators that will, so far as practicable, cure the ill effects of the illegal conduct, and assure the public freedom from its continuance. Such action is not limited to prohibition of the proven means by which the evil was accomplished, but may range broadly through practices connected with acts actually found to be illegal. ${ }^{53}$

Compulsory licensing is one of the forms that such action could take.

The use of the coinpulsory license was further extended in United States v. United Shoe Mach. Corp. ${ }^{54}$ The defendant supphed more than seventy-five per cent of the shoe machinery produced in the United States. In a decree, affirmed by the Supreme Court and based on sections

51 Id. at 336. The decree also covered any patents that would be obtained by National Lead in the following five years.

52 Id. at 338. Justice Douglas, speaking for the three dissenters, protested that the district judge was not able to exercise discretion because he was constrained by language in Hartford-Empire Co. v. United States, 323 U.S. 386, clarified and added to in 324 U.S. 570 (1945), which indicated that, as a matter of law, a royalty-free hiceuse would be unacceptable. Without this inhibition, he argued, the district judge would have ordered royalty-free licensing. Justice Douglas cited authority for the theory that royalty-free licensing would be proper: "The impairment of property rights is no barrier to the fashioning of a decree which will grant effective relief. United States v. Umion Pacific R.R., 226 U.S. 470, 476-77 [1912]. Divestiture or dissolution may be ordered in spite of hardship, inconvenience, or loss. United States v. Crescent Amusement Co., 323 U.S. 173, 189 [1944]:" United States v. National Lead Co., 332 U.S. 319, 366 (1947) (dissenting opimion).

In several notable antitrust consent judgments in recent years royalty-free licensing of patents has been agreed upon by the defendants and the Justice Department. In a consent decree there are no binding findings of fact or conclusions of law. It is possible that the defendants would rather issue royalty-free licenses on a voluntary basis than have a legal precedent established permitting royalty-free licensing. See United States v. General Motors Corp., TrADE REG. REP. (1965 Trade Cas.) II 71,624 (E.D. Mich. Dec. 31, 1965); United States v. Radio Corp. of America, Trade Reg. Rep. (1958 Trade Cas.) II 69,164 (S.D.N.Y. Oct. 28, 1958); United States v. Western Electric, Inc., Trade REG. REP. (1956 Trade Cas.) If 68,246 (D.N.J. Jan. 24, 1956).

53 United States v. United States Gypsum Co., 340 U.S. 76, 88-89 (1950).

54110 F. Supp. 295 (D. Mass. 1953), afjd, 347 U.S. 521 (1954). 
1 and 2 of the Sherman Act, ${ }^{55}$ United Shoe was ordered to grant any applicant, except a dehiberate infringer, a non-exclusive license, at a uniform and reasonable royalty, to use any or all patents held by it. The Court's rationale was cogently stated:

Defendant is not being punished for abusive practices respecting patents, for it engaged in none .... It is being required to reduce the monopoly power it has, not as a result of patents, but as a result of business practices. And compulsory licensing, on a reasonable royalty basis, is in effect a partial dissolution, on a non-confiscatory basis. In regard to patents, as in regard to supply distributorships, the decree does no more than what defendant's own expert recognized would be appropriate if the Court found defendant had monopolized the shoe machinery market. ${ }^{56}$

In essence the Court found that the shoe machniery market would be healthier if more conipanies were in the field. The compulsory license was, at the same time, a way to force United Shoe to let new companies enter the field and a neans of compensating United Shoe for the surrender of the valuable exclusivity of its patent rights.

A recent staff report issued by the Senate Subcommittee on Patents, Trademarks, and Copyrightss, ${ }^{57}$ surveyed those antitrust cases in which conipulsory licensing was included in the remedial decree and found that in some cases the compulsory licensing decrees were effective; in others the decrees did not result in the issuance of any licenses; and in some, according to statements by potential licensees, the decree actually helped the defendant. ${ }^{58}$ The report recommended that the Justice Department carefully scrutinize eacl case in order to determine whether compulsory licensing is an effective remedy, and also recommended consideration of the more severe alternative remedies of divestiture of patent rights or a qualified injunction against the enforcement of the misused patent rights. ${ }^{59}$

5526 Stat. 209 (1890), 15 U.S.C. \$\$ 1-2 (1964).

56 United States v. United Shoe Mach. Corp., 110 F. Supp. 295, 351 (D. Mass. 1953), $a f^{\prime} d, 347$ U.S. 521 (1954). Several civil cases have followed in the wake of the Supreme Court's affirmance of the district court decree. Hanover Shoe, Inc. v. United Shoe Mach. Corp., 245 F. Supp. 258 (M.D. Pa. 1965) (treble damage recovery based on $\S 2$ of the Sherman Act and $\S 4$ of the Clayton Act); Herman Schwabe, Inc. v. United Shoe Mach. Corp., 297 F.2d 906 (2d Cir. 1962) (insufficient evidence to permit jury to make rational determination of damages); International Shoe Mach. Corp. v. United Shoe Mach. Corp., 315 F.2d 449 (1st Cir. 1963) (plaintiff not permitted to introduce government decree, findings and conclusion).

57 Stafp Report of Senate Comanttteg on the Judictary, 86ta Cong., 2Nd Sess., Compulsory Patent Ltcensing Under Antrtrust Jungmennts (Comm. Print 1960).

58 Id. at 6-18.

59 Id. at 52 . The report further recommended several precautionary neasures that could be adopted in the course of negotiating and administering licensing decrees. These measures 


\section{B. Patents that are Used to Restrain Competition in the Marketing of an Unpatented Product}

It has long been held that a patentee may not use his patent to control the marketing of a nonpatented product. ${ }^{60}$ This rule has been based on the notion that the patent monopoly is limited and temporary and that such a use of a patent would constitute an unlawful attempt to enlarge the monopoly. A logical corollary is the Carbice doctrine which states that the owner of a patent cannot maintain a suit for infringement so long as he is using his patent to exercise control over the marketing of a nonpatented product. ${ }^{61}$ The misuse of the patent by the patentee in effect gives the would-be infringer a temporary gratuitous hicense to use the patent. In Morton Salt Co. v. Suppiger $\mathrm{Co}_{0}{ }^{62}$ the plaintiff sought to enjoin Suppiger Co. from infringing its patent covering a machine that dispensed salt tablets. Suppiger claimed that Morton had been using the patented machine to restrain competition in the sale of salt tablets.

may be summarized as follows: (1) The Justice Department could give greater help to private antitrust litigants in determining reasonable royalty rates; (2) the remedial decrees should clearly define the steps the defendant should take; (3) patents that are available for licensing should be advertised in a meaningful way so potential competitors can take advantage of them; (4) reciprocal licensing provisions should be strictly limited so that the remedial decree does not strengthen the defendant's monopoly; (5) the Department of Justice should consult potential licensees to see if they are interested in taking out licenses and, if so, determine which patents are of value; and (6) compulsory licensing should not be used to regulate monopolistic practices which do not involve the misuse of patents; in such cases, dissolution, perbaps by congressional action, would be more appropriate. Id. at 53-54. With respect to the last measure it is important to distinguish between the misuse and the nonuse of a patent. It is legally permissible for a private party to refuse to use his patent. Continental Paper Bag Co. v. Eastern Paper Bag Co., 210 U.S. 405 (1908). Thus it is not illegal per se for a large corporation to buy up patents and not use them. The corporation can be prosecuted, however, for monopolistic trade practices, i.e., for the misuse of the patents. Any general sanctions for the nonuse of the patents must be based on legislative action which, for the present, does not seem to be forthcoming. See Note, 112 U. PA. L. REv. 1025, 1047-48 (1964). The patent laws of some foreign countries contain licensing provisions which can be applied if a patent owner does not use his patent. See Riesenfeld, The New United States Patent Act in the Light of Comparative Law, 36 J. Pat. OfF. Soc'r 406, 444 (1954). See also Vaugran, ThE United States Patent System 312-16 (1956).

The 1954 Atomic Energy Act specifically provides a compulsory licensing remedy if the owner of an atomic energy related patent violates certain provisions of the antitrust laws; these provisions are incorporated by reference in 68 Stat. 938 (1954), 42 U.S.C. $\S$ 2135(a) (1964).

60 See Motion Picture Patents Co. v. Universal Film Mfg. Co., 243 U.S. 502 (1917); Heaton-Peninsular Button-Fastener Co. v. Eureka Specialty Co., 77 Fed. 288 (6th Cir. 1896).

61 Carbice Corp. of America v. American Patents Dev. Corp., 283 U.S. 27 (1931). This doctrine bas been widely followed. See, e.g., B.B. Chem. Co. v. Ellis, 314 U.S. 495 (1942); National Lockwasher Co. v. George K. Garrett Co., 137 F.2d 255 (3d Cir. 1943); Harvey v. Levine, 204 F. Supp. 947, 959 (N.D. Ohio 1962).

62314 U.S. 488 (1942). 
The Court found that Morton would not sell its tablet dispensing machine to a canner unless he would agree to use Morton salt tablets. The Court, as a court of equity, denied relief to Morton until such time as, "the improper practice has been abandoned and ... the consequences of the misuse of the patent have been dissipated." the Court said, "regardless of whether the particular defendant has suffered from the misuse of the patent."

In Mercoid Corp. v. Mid-Continent Inv. Co. ${ }^{85}$ Mid-Continent sued Mercoid for contributory infringement of a patent. Mercoid responded that Mid-Continent had used the patent to restrain competition in the sale of nonpatented elements of the heating system covered by the patent. There was a strong public interest, the Court said, in not allowing the patent monopoly to be extended. Mid-Continent was not granted an injunction because "where an important public interest would be prejudiced,' the reasons for denying injunctive relief 'may be compelling." "180 Mercoid was also told that it could bring a private suit under the Clayton Anti-trust Act. ${ }^{67}$

\section{Licensing of Technical Information in Antitrust Suits}

Most patents, if they are put to use, are utilized in conjunction with manufacturing methods and processes that inay not be patented. In several of the cases previously discussed in which the patent owners were compelled to license their patents, the Supreme Court either ordered or approved a lower court's decree ordering the licensing of technical information covering these methods and processes. ${ }^{88}$ The underlying rationale of the Court appears to be that the companies whose monopolistic practices had cornered the market in an inclustry were being compelled to give their new competitors a chance to compete successfully. ${ }^{60}$

63 Id. at 493 .

64 Id. at 494.

B5 320 U.S. 661 (1944).

${ }^{66}$ Id. at 670. The quoted language is taken from Harrisonville v. Dickey Clay Mfg. Co., 289 U.S. 334, 338 (1933).

${ }^{67} I d$. at 671 . The relevant section of the Clayton Act is 38 Stat. 731 (1914), 15 U.S.C. § 15 (1964).

68 See, e.g., United States v. National Lead Co., 322 U.S. 319, 357 (1947); United States v. United Shoe Mach. Corp., 110 F. Supp. 295, 354 (1953), af'd, 347 U.S. 521 (1954).

${ }^{69}$ In National Lead the Court said, "The justification for the compulsory imparting of methods and processes rests upon its appropriateness and upon the necessity for it in providing an effective decree." United States v. National Lead Co., 332 U.S. at 357. Because nearly all commercial titanium products were covered by patents, a newcomer would not have been able to produce such products and, therefore, would not have been able to develope its own manufacturing methods and processes. The Court concluded that a need for the information had been demonstrated and that the assessment of a reasonable charge obviated the objection by one of the parties that this portion of the licensing provision was pumitive. Id. at 357-58. 


\section{III}

\section{GENERAL TRADE SECRET LICENSING}

It is doubtful that a trade secret is property; rather, a trade secret is normally a process or formula that is exclusively possessed until it is independently discovered by someone else. ${ }^{70}$ However, the owner of knowhow that is combined in such a way as to be special-that is, something that anyone could develop but not without investing money and allocating manpower-does have a right to require employees to retain information in confidence. ${ }^{71}$ When breaches of this confidence occur, the employer has traditionally been able to obtam an accounting, recover damages and, in most instances, enjoin the employee from using the information he was given in confidence. ${ }^{72}$

\section{A. Secret Ingredient Formulas}

Secret ingredient formulas are normally trade secrets and need not be divulged. The Supreme Court, however, has held that it can be within the police power of the state to require their disclosure. In Corn Products Ref. Co. v. $E d d y,^{73}$ the Court upheld a regulation issued by the Kansas State Board of Health that required the labels of syrup containers to list "in conspicuous letters, the percentage of each ingredient, in the case of compounds, mixtures, imitations or blends."74 Similarly, in a later case the Court held that a state could require that sacks of fertilizer show a chemical analysis of the ingredients and their concentrations. "The right of a manufacturer to maintain secrecy as to his compounds and processes must be held subject to the right of the State, in the exercise of its police power and in promotion of fair dealing, to require that the

$70 \mathrm{In}$ an oft-cited opinion, Justice Holmes emphasized that a trade secret is property only in the sense that a person to whom the secret is related in confidence is under a duty not to disclose it: "The word property as apphied to trade-marks and trade secrets is an unanalyzed expression of certain secondary consequences of the primary fact that the law makes some rudimentary requirements of good faith." E.I. DuPont de Demours Powder Co. v. Masland, 244 U.S. 100, 102 (1917). See also Sarkes Tarzian, Inc. v. Audio Devices, Inc., 166 F. Supp. 250 (S.D. Cal. 1958); Arnold, A Philosophy on the Protections Afforded by Patent, Trademark, Copyright and Unfair Competition Law, 54 Tradeacark REP. 413, 429-30 (1964).

71 Trade secrets may be processes that could be patented or they may be combinations of know-how which do not meet the requirements of patentability. Even if a process is patentable a company may decide to keep it secret rather than publish the secret in exchange for the limited patent monopoly. See Herald, Trade Secrets as an Alternative to Patents, 9 AM. L. REv. 1107 (1941).

72 See generally Note, Injunctions to Protect Trade Secrets, 51 VA. L. Rev. 917, 923-31 (1965); TURNER, LAW OF TRAdE SEcreTS 281-306, 350-59 (1962); 2 CaILMANN, The Law of Unfair Competition and Tradeacarks \$ 59 (2d ed. 1950).

73249 U.S. 427 (1919).

74 Id. at 431 . 
nature of the product be fairly set forth." "' In effect, to prevent adulteration and misbranding, the manufacturer is told that if he wants to market his product he cannot keep its composition secret. ${ }^{70}$

\section{B. Licensing in the National Interest}

In Space Aero Prods. Co. v. R. E. Darling Co., ${ }^{77}$ a Maryland court was faced with a typical trade secret case whicl was complicated by the supervention of the national interest. Darling was an estabhshed manufacturer of specialty rubber hoses. In January, 1961, four former employees of Darling, who had terminated their employment in December, 1960, formed a competing company, Space Aero. Within a month after incorporation, Space Aero met the standards of a military specification for an oxygen breathing hose used by jet pilots and was awarded a contract. Until then Darling had been the only company that had been able to qualify under that type of specification. Darling sued for a permanent injunction to restrain Space Aero from using trade secrets belonging to it, for an accounting of profits, for damages, and for an order directing Space Aero to deliver up any documents belonging to Darling.

The trial judge decided that the four employees had breached the duty of fidelity and trust they owed to their former employer by utilizing trade secrets they had obtained while working for Darling. ${ }^{78}$ Space Aero was ordered to refrain from " 'further manufacture and/or sale' of oxygen breathing hoses 'of hike or similar construction to hose assemblies manufactured to the requirements of United States Military Specification Mil H-22489.' "7t It was also orclered to deliver immediately to the court for destruction "'any and all drawings, manuals, clocuments and other materials in their possession which clescribe or disclose the equipment, components, methods or techniques utilized in the manufacture of those liose assemblies.' " that the national defense would be adversely affected if Space Aero were

\footnotetext{
75 National Fertilizer Ass'n, Inc. v. Bradley, 301 U.S. 178, 182 (1937). The quoted language is taken from Corn Products Ref. Co. v. Eddy, 249 U.S. 427, 431-32 (1919).

76 The police power of the state has been held adequate to require, e.g., the listing of the ingredients of paints, Heath \& Milligan Mfg. Co. v. Worst, 207 U.S. 338 (1907), Lasting Prods. Co. v. Genovese, 197 Va. 1, 87 S.E.2d 811 (1955), and of poisons, Gregory v. Hecke, 73 Cal. App. 268, 238 Pac. 787 (1925).

77238 Md. 93, 208 A.2d 74, nodified, 238 Md. 129, 208 A.2d 699 (1965), cert. denied, 382 U.S. 843 (1965).

${ }^{78}$ Space Aero Prods. Co. v. R. E. Darling Co., 238 Md. 93, 103, 208 A.2d 74, 78, modified, 238 Md. 129, 208 A.2d 699, cert. denied, 382 U.S. 843 (1965). For a discussion of the limits of the confidence deemed to exist beween the employer and employee see McClain, Injunctive Relief Against Employees Using Confidential Information, $23 \mathrm{KX}$. L.J. 248, 265 (1935).

79 Space Aero Prods. Co. v. R. E. Darling Co., supra note 78, at 103, 208 A.2d at 78.

${ }^{80}$ Id. at 103-04, $208 \mathrm{~A} .2 \mathrm{~d}$ at 78.
} 
enjoined from completing certain military contracts. Thereafter a motion for a modified injunction was demed without a hearing.

The court discussed the two prevalent damage rules that are applied in trade secret cases, the Conmar rule and the Shellmar rule, ${ }^{81}$ and adopted the Conmar rule because it operated less harshly on the defendants. The court said, "Our conclusion that this rule should be apphied to the present case is fortified by the specific and important public interest here involved." ${ }^{182}$ By operation of this rule the defendants would be enjoined only until a third manufacturer was able to make this type of hose. The court would not, however, limit the scope of the injunction insofar as it prohibited the defendants from making a product bike or similar to that described in the military specification; but it stated its willingness to allow Space Aero to complete their contracts with the government.

A second Navy affidavit, similar to the one filed in the trial court, was then filed with the court. ${ }^{83}$ It outlined the interest of the national defense: Space Aero and Darling were the only contractors who could supply an urgently needed hose assembly, and the delay im letting new contracts to Darling would imperil the safety of Navy fighter pilots. The Navy promised the court that Space Aero would not be given new contracts which would require the kind of work covered by the injunction. On the strength of this affidavit, the court modified the injunction to permit Space Aero to complete its contracts with the Navy or its contractors if a lower court were to determine that noncompletion would adversely affect the national defense. ${ }^{84}$ The court reiterated its holding that Darling could recover damages. ${ }^{85}$

81 The Conmar rule states that "the trade secret is protectible only because of the fiduciary relationship of the discloser to the disclosee. Once the secret is public, the confidence would end in any event." Id. at 123, 208 A.2d at 90. Thus damages awarded for the loss of a trade secret would ouly cover the interim period. This rule is derived from the decision in Conmar Products Corp. v. Universal Slide Fastener Co., 172 F.2d 150 (2d Cir. 1949). The Shellmar rule provides that an injunction will be permanent and will be enforced even if the trade secret subsequently becomes common knowledge as a result of an independent discovery. "The wrongdoer has deprived himself of the opportunity, open to the rest of the world, by his own violation of confidence." Id. at 124, 208 A.2d at 90. If damages were to be awarded under this rule they would cover the loss to the confiding party caused by the party who breached the confidence. This rule was derived from the decision in Shellmar Products Co. v. Allen-Qualley Co., 87 F.2d 104 (7th Cir. 1936), cert. denied, 301 U.S. 695 (1937).

82 Space Aero Prods. Co. v. R. E. Darling Co., 238 Md. 93, 125, 208 A.2d 74, 91, modified $238 \mathrm{Md} .129,208$ A.2d 699, cert. denied, 382 U.S. 843 (1965).

83 Space Aero Products Co. v. R. E. Darling Co., 238 Md. 129-30, 208 A.2d 699, 700, modifying 238 Md. 93, 208 A.2d 74 (1965), cert. denied, 382 U.S. 843 (1965).

84 Id. at 130, $208 \mathrm{~A} .2 \mathrm{~d}$ at 700 . The court also modified the injunction so that employees of Space Aero other than the four former Darling employees were not prohibited from using their skills so long as they did not work on pressure hose assemblies constructed like Darling's and use Darling's secret processes. Id. at 131, 208 A.2d at 701.

85 Id. at 130, 208 A.2d at 701. This result is an offshoot of the general principle of 
The net result is that Space Aero obtained a compulsory license to use the trade secrets of Darling; the license was limited in duration but any royalties thereunder would have to be based on a showing that Darling was damaged. If Space Aero had been given an unlimited license, Darhing could have more easily shown damage; it could have shown that Space Aero would be able to compete with it in bidding for other pressure hose contracts..$^{86}$

In this situation the compulsory license operates to deny an innocent party the form of recovery that he would otherwise obtain. The compulsory license which results from the supervention of the national interest could be a harsh imposition on Darhing or it could be a reasonable compromise. If the alternative remedy of damages proves to be valueless, then Space Aero has obtained a royalty-free license. If reasonable damages are recovered, Darling las only been compelled to grant a temporary license for a reasonable royalty.

\section{CONCLUSTON}

The party who has absconded with a trade secret, the company that has not invested money in a field because other companies have already expended large sums of capital and, as a result, have cornered the available patents, and the manufacturer who has infringed a patent (perhaps deliberately) but who is performing a service for the publicthese are not parties who have been severely wronged and need a redress of their greivance. They are given protection only because their interests happen to coincide with important public interests. In effect, a situation exists in which the public interest is a third party which has intervened in litigation between two private parties and has altered the outcome of the litigation.

When Congress decides that the Atomic Energy Commission should carefully control, by licensing, the available patents and know-how in the

equity known as the balancing of equities or the balancing of conveniences or hardships. One authority states the principle in the following manner: "The doctrine or rule is sometimes stated to be that the court will weigh the loss, injury, or hardship resulting to the respective parties from granting or withholding equitable relief; that if the loss resulting to the plaintiff from denying the equitable relief will be shight as compared to the loss or hardship caused to the defendant if the injunction is granted, the equitable relief will be denied." DE FunIAK, HANDBOOK of MODERN EQUTTY 43 (2d ed. 1956). de Funiak then notes that when the public interest intervenes, "the hardship upon or great inconvenience to the public outweighs any right, however substantial, of the plaintiff to relief, and he is left to his remedy in damages." Id. at 45 .

86 Even then, lowever, the damages might lave been speculative because Maryland follows the Conmar rule. Space Aero would lawfully be able to use the trade secrets as soon as a third company discovered the process. Thus Darling was damaged only by the loss of exclusive knowledge for a period that would end if a third company discovered the secret process. 
atomic energy field, when a state requires the histing of secret ingredients on labels, or when the Congress prescribes the property rights in inventions to be accorded to government contractors, the public interest is directly involved. A situation exists in which there are but two interested parties: the public and the private individual.

The import of the solutions reached in the two basic situations presented in this Comment is that the compulsory license is a compromise. Property rights in patents and trade secrets are granted by statute or are created by common law precepts. These types of property may be privately held. But they are either peculiarly susceptible of being used as instruments to create monopolies or have a particularly vital public use. When monopolies are created, or when they may be created, or when a public necessity exists, the right to hold these types of property must be abridged; but in most cases the riglit may not or need not be abolished. The compulsory license allows abridgement without abohtion.

Norman Ernest Reitz 